\title{
Multislice computed tomographic measurements of optic nerve sheath diameter in brain injury patients
}

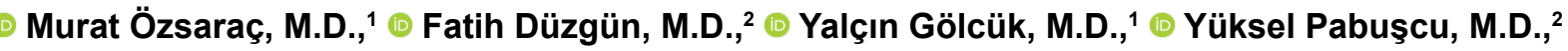 \\ (ㄷ) Adnan Bilge, M.D., ${ }^{1}$ @ Mehmet İrik, M.D., ${ }^{1}$ - Halil Yılmaz, M.D. ${ }^{1}$
}

${ }^{1}$ Department of Emergency Medicine, Celal Bayar University Faculty of Medicine, Manisa-Turkey

${ }^{2}$ Department of Radiology, Celal Bayar University Faculty of Medicine, Manisa-Turkey

\begin{abstract}
BACKGROUND: Currently, the measurement of optic nerve sheath diameter (ONSD) has been offered as a possible indicator of intracranial pressure (ICP). Increased ICP is observed during intracranial injury. The objective of this study was to evaluate the relationship between increased ONSD and positive intracranial findings from multislice computed tomography (CT) of the brain.

METHODS: In total, CT scans of I6I patients were retrospectively reviewed. The image that showed the largest ONSD was magnified five times.

RESULTS: The CT scan revealed intracranial lesions in 54 patients and no intracranial lesions in 107 patients. A significant relationship was observed between positive CT findings and increased ONSD: $5.60 \pm 0.75 \mathrm{~mm}$ vs. $5.35 \pm 0.75 \mathrm{~mm}(p=0.038)$. The area under the receiver operating characteristic curve was 0.600 (95\% confidence interval, $0.508-0.692 ; p<0.039)$. A cut-off value of $\geq 5.0 \mathrm{~mm}$ had a sensitivity and specificity of $80 \%$ and $36 \%$, respectively.
\end{abstract}

CONCLUSION: This study demonstrated a significant yet poor relationship between intracranial injury and increased ONSD from the multislice CT scan. Severe structural changes in the brain and trauma that causes bleeding have only limited effects on the extension of the optic nerve.

Keywords: Brain injury; computed tomography, intracranial hypertension; intracranial pressure; optic nerve sheath diameter.

\section{INTRODUCTION}

Intracranial hypertension is a critical syndrome and is caused by a variety of neurological problems. If elevated intracranial pressure (ICP) is undetected and left untreated, progressive deterioration of neuronal activity and even death may occur. [I] Intracranial compliance deteriorates quickly with the expansion of space-occupying lesions, cerebral edema, hypoxia, tumor complications, head trauma, or hematoma due to the rigid structure of the skull and restricted compensatory growth. ${ }^{[2]}$ Patients with these conditions may require expeditious surgical or medical intervention to prevent a poor outcome. ${ }^{[3]}$ In traumatic brain injuries (TBIs), the mass effect of hematoma, loss of autoregulation, and increased internal pressure of the thorax and abdomen due to mechanical ventilation promote the development of intracranial hypertension. [4] The diagnosis of ICP is very important because prompt treatment is essential for limiting neuronal injury, but physical examination has its limitations. ${ }^{[5]}$ Methods including lumbar puncture, ventriculostomy, magnetic resonance imaging (MRI), or computed tomography (CT) may be used in ICP diagnosis; however, these options are invasive, time-consuming, expensive, and often not feasible. Currently, the measurement of optic nerve sheath diameter (ONSD) by ultrasonography has been offered as a possible indicator for ICP. ${ }^{[6-9]}$ The optic nerve is a component of the brain and is enveloped by cerebrospinal fluid and a subarachnoid membrane. Intracranial trauma and elevated pressure can arise from a variety of

Cite this article as: Özsaraç M, Düzgün F, Gölcük Y, Pabuşcu Y, Bilge A, İrik M, et al. Multislice computed tomographic measurements of optic nerve sheath diameter in brain injury patients. Ulus Travma Acil Cerrahi Derg 2018;24:316-320.

Address for correspondence: Murat Özsaraç, M.D.

Celal Bayar Üniversitesi Tıp Fakültesi, Acil Tıp Anabilim Dalı, Manisa, Turkey.

Tel: +90 236 - 2338586 E-mail: mozsarac@msn.com

Ulus Travma Acil Cerrahi Derg 2018;24(4):316-320 DOI: 10.5505/tjtes.2017.27985 Submitted: 28.06.2016 Accepted: 18.10.2017 Online: 26.06.2018

Copyright 2018 Turkish Association of Trauma and Emergency Surgery 
reasons, such as bleeding, tumor, and hydrocephalus, which directly affect the optic nerve through the subarachnoid area, causing dilation of the nerve body. ${ }^{[6,10]}$ A prospective study on emergency medicine and critical care unit patients with TBI suggested that an increase in ONSD of $>5.0-6.3 \mathrm{~mm}$ (measured $3 \mathrm{~mm}$ behind the globe) is an indicator of increased ICP. ${ }^{[5,7,8,11-20]}$ On the other hand, the reported average ONSD measurement is uncertain. The experience level of the medical practitioner, variation in ultrasound technique, artifacts in the image, and the small structural size of the nerve may all contribute to a wide variation in the exact cut-off value. [II-22] Ultrasonographic attenuation artifacts can originate from the optic disc and lens, causing incorrect evaluation of ONSD. The imprecise, homogeneous, hypoechoic, bandshape appearance of these artifacts and the need to perform millimetric measurements within a narrow area both affect the reliability of measurement. Moreover, dynamic variations in ICP are not frequently considered. ${ }^{[21]}$ CT is considered a more effective method for the evaluation of increased ICP on the optic nerve, especially that which arises from severe head trauma and which causes severe brain hemorrhage. An accurate visualization of the size of the optic nerve from thinslice CT images may provide more precise results. It may also be beneficial in determining more accurate threshold values of the optic nerve. The objective of this study was to evaluate the relationship between increased ONSD and positive intracranial findings from multislice CT scans of the brain.

\section{MATERIALS AND METHODS}

This retrospective study was conducted at a university hospital in the emergency department, with an approximate patient volume of 60000 per year. The protocol for this study was reviewed and approved by the institutional ethics committee of Manisa Celal Bayar University. Brain CT images (minimum of 300 sequences) over a 2-year period from January 2014 to March 2016 were obtained from the emergency department and reviewed. The inclusion criteria comprised patients (male or female) aged $>17$ years and who were diagnosed with a focal brain injury. Positive CT findings were defined as intraventricular or subarachnoid hemorrhage; epidural, subdural, or parenchymal hematoma; or cerebral contusion. Patients were identified using the International Classification of Diseases Ninth Revision diagnosis codes for concussion, epidural hematoma, subdural hemorrhage, subarachnoid hemorrhage, intracranial injury, and skull fracture (ICD codes S00, S02, S06). Brain CT images, reports, and ONSD measurements of all patients were reviewed. Non-trauma patients with spontaneous intracranial hemorrhage were also included. Asymmetric scans with a low number of image section scans (such as 40 or 50 sections) and/or with artifacts for any reason (severe fracture, abnormal eye motion, or foreign bodies) that could cause inaccuracies in the ONSD evaluation and create CT images with unusual ophthalmic findings were excluded. Besides these, patients with optic nerve trauma and a history of intracranial mass were excluded from this study. Among the patients included in the ICD list (registered as a preliminary diagnosis), patients who did not have any type of intracranial injury apparent on CT were evaluated as the normal CT group. Every brain CT image was interpreted and reported by an expert radiologist. The results of the ONSD measurements taken from the brain CT images were evaluated by emergency physicians. The mean ONSD of the patients' left and right eyes was calculated to yield the median value. The width of ONSD was also determined from the CT images and evaluated perpendicularly to the axial CT image. The images were evaluated through the only "brain window," which demonstrated ONSD in complete and greatest detail. ONSD was measured $3 \mathrm{~mm}$ behind the globe in a perpendicular vector, with reference to the linear axis of the nerve (Fig. I). Measurements were evaluated using a picture archiving and communication system workstation by Probel $^{\circledR}$. The image that demonstrated the largest ONSD was magnified five times.

\section{Statistical Analysis}

All data were analyzed using the software SPSS Statistics Version 15.0 for Windows. Categorical data were presented as percentages. Numerical data were presented as mean \pm standard deviation as well as median (min-max), and the assumption of normality was tested using the Kolmogorov-Smirnov test. The Mann-Whitney $U$ test was also performed to evaluate the relationship between intracranial findings and ONSD. The significance was set to $p \leq 0.05$. The receiver operating characteristic (ROC) curves were drawn to determine the performance of increased ONSD to predict positive intracranial finding and its area under the curve was used. In addition, once the best cut-off value had been determined from graphical data, sensitivity and specificity were calculated with $95 \%$ confidence intervals (Cls).

\section{RESULTS}

Between January 2014 and March 2016, a total of 2,700 patients were examined in the emergency department for head trauma and intracranial injury (ICD codes S00: superficial injuries of the head and face; S02: skull fractures; and S06: intracranial hemorrhage). In total, data from $16 \mathrm{I}$ patients with an injury or fracture were analyzed. CT was performed in these patients to identify trauma or symptoms. The age range

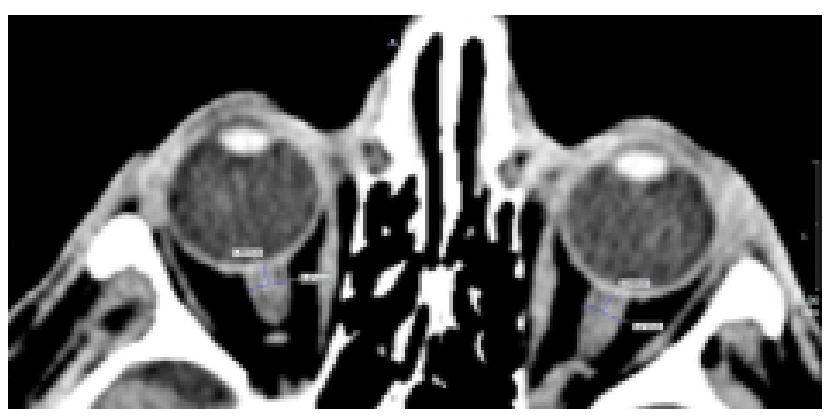

Figure 1. Multislice computed tomography measurements of bilateral optic nerve sheath diameter. 
Table I. Brain computed tomography (CT) findings and mean optic nerve sheath diameter measurement

\begin{tabular}{lcc}
\hline & $\begin{array}{c}\text { Intracranial lesion positive } \\
(\mathbf{n = 5 4 )}\end{array}$ & $\begin{array}{c}\text { Intracranial lesion negative } \\
(\mathbf{n}=\mathbf{1 0 7})\end{array}$ \\
\hline Mean diameter (mm) & $5.60 \pm 0.75$ & $5.35 \pm 0.75$ \\
Normal computed tomography findings & $94(58.4 \%)$ \\
Isolated fracture (i.e., nasal, maxilla and mandibula) & $8(5 \%)$ & $13(8.1 \%)$ \\
Epidural hematoma & $18(11.2 \%)$ & \\
Subdural hematoma & $6(3.7 \%)$ & \\
Subarachnoid hemorrhage & $22(13.7 \%)$ & \\
Parenchymal hematoma, contusion, and mixed type injuries &
\end{tabular}

*Mann-Whitney U Test.

of patients was 17-86 years, with an average of 40.1 years; I 4 patients were males (70.8\%) and 47 were females (29.2\%). The

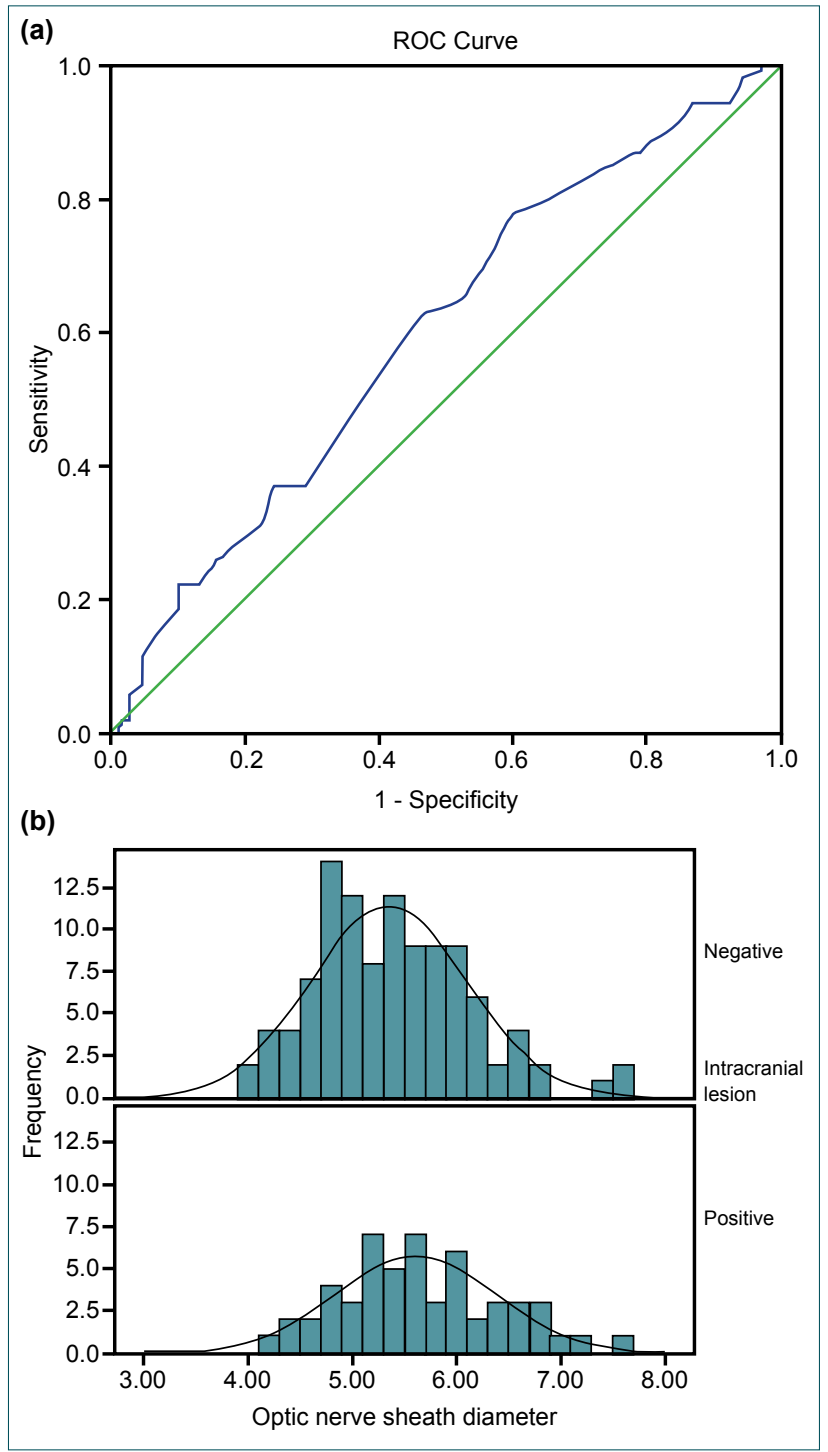

Figure 2. (a, b) Receiver-operator characteristic curves of the performance of optical nerve sheath diameter to predict positive CT findings. initial brain CT scan revealed intracranial lesions (i.e., epidural hematoma, subdural hematoma, subarachnoid hemorrhage, contusion, or mixed types of injury) in 54 patients (33.5\%) and no intracranial lesions in 107 patients (66.5\%). The type of injury was trauma in 40 cases (74.1\%) and non-trauma in 14 cases $(25.9 \%)$. A summary of the patients' radiological data is presented in Table I. A significant relationship was observed

Table 2. Optimal threshold for optic nerve sheath diameter in previous studies

\begin{tabular}{|c|c|c|}
\hline Author & $\begin{array}{l}\text { Number of } \\
\text { patients }\end{array}$ & $\begin{array}{l}\text { Optimal cut-off } \\
\text { (optic nerve) }\end{array}$ \\
\hline Kimberly et al. ${ }^{[5]}$ & 15 & $\begin{array}{l}5.0 \mathrm{~mm} \text { (sensitivity } 88 \% \text { and } \\
\text { specificity of } 93 \% \text { ) }\end{array}$ \\
\hline Blaivas et al. ${ }^{[1]}$ & 35 & $\begin{array}{l}6.3 \mathrm{~mm} \text { (sensitivity } 100 \% \\
\text { and specificity } 95 \% \text { ) }\end{array}$ \\
\hline Tayal et al. ${ }^{[12]}$ & 59 & $\begin{array}{l}5.0 \mathrm{~mm} \text { (sensitivity } 100 \% \text { and } \\
\text { specificity } 63 \% \text { ) }\end{array}$ \\
\hline Frumin et al. ${ }^{[13]}$ & 27 & $\begin{array}{l}5.2 \mathrm{~mm} \text { (sensitivity } 83 \% \text { and } \\
\text { specificity } 100 \% \text { ) }\end{array}$ \\
\hline Sekhon et al. ${ }^{[14]}$ & 57 & $\begin{array}{l}6.0 \mathrm{~mm} \text { (sensitivity } 97 \% \text { and } \\
\text { specificity } 42 \% \text { ) }\end{array}$ \\
\hline Geeraerts et al. ${ }^{[15]}$ & 31 & $\begin{array}{l}5.7 \mathrm{~mm} \text { (sensitivity } 100 \% \text { and } \\
\text { specificity } 100 \% \text { ) }\end{array}$ \\
\hline Soldatos et al..$^{[17]}$ & 76 & $\begin{array}{l}5.7 \mathrm{~mm} \text { (sensitivity } 74 \% \text { and } \\
\text { specificity } 100 \% \text { ) }\end{array}$ \\
\hline Moretti et al. ${ }^{[18]}$ & 53 & $\begin{array}{l}5.2 \mathrm{~mm} \text { (sensitivity } 94 \% \text { and } \\
\text { specificity } 76 \% \text { ) }\end{array}$ \\
\hline Rajajee et al. ${ }^{[19]}$ & 65 & $\begin{array}{l}5.2 \mathrm{~mm} \text { (sensitivity } 67 \% \text { and } \\
\text { specificity } 98 \% \text { ) }\end{array}$ \\
\hline Amini et al. ${ }^{[20]}$ & 50 & $\begin{array}{l}5.5 \mathrm{~mm} \text { (sensitivity } 100 \% \text { and } \\
\text { specificity } 100 \% \text { ) }\end{array}$ \\
\hline Caffery et al. ${ }^{[26]}$ & 51 & $\begin{array}{l}5.0 \mathrm{~mm} \text { (sensitivity } 75 \% \text { and } \\
\text { specificity } 44 \% \text { ) }\end{array}$ \\
\hline
\end{tabular}


between positive CT findings and increased ONSD: $5.60 \pm 0.75$ $\mathrm{mm}$ vs. $5.35 \pm 0.75 \mathrm{~mm}(\mathrm{p}=0.038)$. An ROC curve was placed to evaluate the diagnostic significance of ONSD (Fig. 2a and b). Comparing positive and negative intracranial findings on $\mathrm{CT}$, the positive findings presented more signs of increased ONSD. The area under the ROC curve was $0.600(95 \% \mathrm{Cl}$, $0.508-0.692 ; p<0.039$ ). A cut-off value of $\geq 5.0 \mathrm{~mm}$ had a sensitivity and specificity of $80 \%$ and $36 \%$, respectively.

\section{DISCUSSION}

The traditional indicators for elevated ICP in brain CT include cisternal compression, sulcal effacement, changes in vertical sizes, midline shift with a mass effect of at least 3 $\mathrm{mm}$, transtentorial herniation, and changes in the rate of gray/ white matter. ${ }^{[23]} \mathrm{CT}$ remains the most commonly available tool for intracranial hypertension diagnosis, and ONSD measurements by MRI are shown in correlation with direct ICP measurements. ${ }^{[5,7,14]}$ ONSD measurements via MRI and CT are compatible, with the latter method being widely available for patients with $\mathrm{TBI}^{[5,6,9]}$ However, these modalities require the transfer of a patient in critical condition away from the resuscitation area. ${ }^{[24]}$

A previous study on healthy individuals and glaucoma patients reported high correlation between tomographic and ultrasonographic ONSD measurements. ${ }^{[25]}$ Numerous contemporary reports have found that ONSD is correlated with elevated ICP, as measured by invasive ICP monitoring. [7,8,15,18-21] Besides, ultrasound may be of use in the assessment of patients with suspected intracranial hypertension. Simple bedside ONSD measurements have been developed for faster assessment of high ICP risk. The non-invasive and rapid quality of bedside ultrasound has resulted in an increase in its use for detecting intracranial hypertension by the emergency department and critical care unit. Unfortunately, there has been no agreement on the optimal thresholds of normal and increased ONSD indicating intracranial hypertension. $[2,5,7,8,11-15,18-21]$ Recent studies on the subject are summarized in Table 2. Previous studies have considered the cut-off range for ONSD in predicting elevated ICP to be $5.0-6.3 \mathrm{~mm}$. In the literature, the sensitivity and specificity widely ranged from $74 \%-100 \%$ and $48 \%-100 \%$, respectively. The normal limits in one study might not be normal in another study. ${ }^{[5,11-26]}$ Amini et al. determined that the threshold value of ONSD at higher sensitivity and specificity levels was $5.5 \mathrm{~mm}$ in patients with an elevated lumbar puncture opening pressure of $>20 \mathrm{~cm}$ H2O. ${ }^{[20]}$ In addition, Caffery et al. reported that the threshold value of $5.0 \mathrm{~mm}$ did not have adequate sensitivity and specificity, despite using the same methodology. ${ }^{[26]}$ Regarding the ultrasonographic image quality in particular, artifacts and user experience are the most significant factors for presenting different threshold values. ${ }^{[I]}$

Increased ICP can be observed during the natural period of intracranial injury. In cases of head injury, ONSD can be a valuable tool for analysis in broader prospective trials and in the determination of critical cases. For patients with head injuries, there is a need for combined clinical studies in which ultrasound measurements are corroborated with thin-slice CT measurements. Additional prospective studies on ultrasonography and CT may be justified to evaluate diagnostic performance and risk stratification.

In this study, an analysis of CT images with $5 \times$ magnification could allow for sharper appearance of optic nerve borders and a more accurate evaluation of sizes. In this study, statistical differences were found between ONSDs of patients with intracranial injury and patients without; however, the differences did not present much clinical significance $(5.60 \mathrm{~mm}$ vs. $5.35 \mathrm{~mm}$ ). Finally, current clinical and radiological studies do not provide a precise ONSD cut-off value for measuring increased ICP. ${ }^{[7,22]}$

\section{Conclusion}

This study demonstrated a significant yet poor relationship between intracranial injury and increased ONSD from the initial multislice brain CT scan. Severe structural changes in the brain and severe trauma that causes bleeding have only limited effects on the extension of the optic nerve.

\section{Acknowledgments}

We thank Dr. Hatice Uluer (Ege University, Biostatistics And Medical Informatics, İzmir) for their assistance in data analysis and table editing.

Conflict of interest: None declared.

\section{REFERENCES}

1. Stein DM, Hu PF, Brenner M, Sheth KN, Liu KH, Xiong W, et al. Brief episodes of intracranial hypertension and cerebral hypoperfusionare associated with poor functional outcome after severe traumaticbrain injury. J Trauma 2011;71:364-73; discussion 373-4. [CrossRef]

2. Treggiari MM, Schutz N, Yanez ND, Romand JA. Role of intracranial pressure values and patterns in predicting outcome in traumatic brain injury: a systematic review. Neurocrit Care. 2007;6:104-12. [CrossRef]

3. Münch EC, Bauhuf C, Horn P, Roth HR, Schmiedek P, Vajkoczy P. Therapy of malignant intracranial hypertension by controlled lumbar cerebrospinal fluid drainage. Crit Care Med 2001;29:976-81. [CrossRef]

4. Rangel-Castilla L, Gopinath S, Robertson CS. Management of intracranial hypertension. Neurol Clin 2008;26:521-41. [CrossRef]

5. Kimberly HH, Shah S, Marill K, Noble V. Correlation of optic nerve sheath diameter with direct measurement of intracranial pressure. Acad Emerg Med 2008;15:201-4. [CrossRef]

6. Chen H, Ding GS, Zhao YC, Yu RG, Zhou JX. Ultrasound measurement of optic nerve diameter and optic nerve sheath diameter in healthy Chinese adults. BMC Neurol 2015;15:106. [CrossRef]

7. Geeraerts T, Newcombe VF, Coles JP, Abate MG, Perkes IE, Hutchinson PJ, et al. Use of T2-weighted magnetic resonance imaging of the optic nerve sheath to detect raised intracranial pressure. Crit Care 2008;12:R114. [CrossRef] 
8. Kimberly HH, Noble VE. Using MRI of the optic nerve sheath to detect elevated intracranial pressure. Crit Care 2008;12:181. [CrossRef]

9. Kalantari H, Jaiswal R, Bruck I, Matari H, Ghobadi F, Weedon J, et al. Correlation of optic nerve sheath diameter measurements by computed tomography and magnetic resonance imaging. Am J Emerg Med 2013;31:1595-7. [CrossRef]

10. Killer HE, Laeng HR, Flammer J, Groscurth P. Architecture of arachnoid trabeculae, pillars, and septa in the subarachnoid space of the human optic nerve: anatomy and clinical considerations. Br J Ophthalmol 2003:777-81. [CrossRef]

11. Blaivas M, Theodoro D, Sierzenski PR. Elevated intracranial pressure detected by bedside emergency ultrasonography of the optic nerve sheath. Acad Emerg Med 2003;10:376-81. [CrossRef]

12. Tayal VS, Neulander M, Norton HJ, Foster T, Saunders T, Blaivas M. Emergency department sonographic measurement of optic nerve sheath diameter to detect findings of increased intracranial pressure in adult head injury patients. Ann Emerg Med 2007;49:508-14. [CrossRef]

13. Frumin E, Schlang J, Wiechmann W, Hata S, Rosen S, Anderson C, et al. Prospective analysis of single operator sonographic optic nerve sheath diameter measurement for diagnosis of elevated intracranial pressure. West J Emerg Med 2014;15:217-20. [CrossRef]

14. Sekhon MS, Griesdale DE, Robba C, McGlashan N, Needham E, Walland $\mathrm{K}$, et al. Optic nerve sheath diameter on computed tomography is correlated with simultaneously measured intracranial pressure in patients with severe traumatic brain injury. Intensive Care Med 2014;40:126774. [CrossRef]

15. Geeraerts T, Launey Y, Martin L, Pottecher J, Vigué B, Duranteau J, et al. Ultrasonography of the optic nerve sheath may be useful for detecting raised intracranial pressure after severe brain injury. Intensive Care Med 2007;33:1704-11. [CrossRef]

16. Legrand A, Jeanjean P, Delanghe F, Peltier J, Lecat B, Dupont H. Estimation of optic nerve sheath diameter on an initial brain computed tomography scan can contribute prognostic information in traumatic brain injury patients. Crit Care 2013;17:R61. [CrossRef]

17. Soldatos T, Karakitsos D, Chatzimichail K, Papathanasiou M, Gouliamos A, Karabinis A. Optic nerve sonography in the diagnostic evaluation of adult brain injury. Crit Care. 2008;12:R67. [CrossRef]

18. Moretti R, Pizzi B. Optic nerve ultrasound for detection of intracranial hypertension in intracranial hemorrhage patients: confirmation of previous findings in a different patient population. J Neurosurg Anesthesiol 2009;21:16-20. [CrossRef]

19. Rajajee V, Vanaman M, Fletcher JJ, Jacobs TL. Optic nerve ultrasound for the detection of raised intracranial pressure. Neurocrit Care 2011;15:506-15. [CrossRef]

20. Amini A, Kariman H, Arhami Dolatabadi A, Hatamabadi HR, Derakhshanfar H, Mansouri B, et al. Use of the sonographic diameter of optic nerve sheath to estimate intracranial pressure. Am J Emerg Med 2013;31:236-9. [CrossRef]

21. Moretti R, Pizzi B. Ultrasonography of the optic nerve in neurocritically ill patients. Acta Anaesthesiol Scand 2011;55:644-52. [CrossRef]

22. Shevlin C. Optic nerve sheath ultrasound for the bedside diagnosis of intracranial hypertension: pitfalls and potential. Critical Care Horizons 2015;1:22-30.

23. Miller MT, Pasquale M, Kurek S, White J, Martin P, Bannon K, et al. Initial head computed tomographic scan characteristics have a linearrelationship with initial intracranial pressure after trauma. J Trauma 2004 May;56:967-72. [CrossRef]

24. Romagnuolo L, Tayal V, Tomaszewski C, Saunders T, Norton HJ. Optic nerve sheath diameter does not change with patient position. Am J Emerg Med 2005;23:686-8. [CrossRef]

25. Boles Carenini B, Tettoni E, Brogliatti B. CT and a echography of optic nerve in glaucoma. Acta Ophthalmol Scand Suppl 2002;236:40-1.

26. Caffery TS, Perret JN, Musso MW, Jones GN. Optic nerve sheath diameter and lumbar puncture opening pressure in nontrauma patients suspected of elevated intracranial pressure. Am J Emerg Med 2014;32:1513-5. [CrossRef]

\section{ORIJINAL ÇALIŞMA - ÖZET}

\section{Beyin hasarı olan hastalarda çok kesitli bilgisayarlı tomografide optik sinir kılıfı ölçümleri \\ Dr. Murat Özsaraç, ${ }^{1}$ Dr. Fatih Düzgün, ${ }^{2}$ Dr. Yalçın Gölcük, ${ }^{1}$ Dr. Yüksel Pabuşcu, ${ }^{2}$ \\ Dr. Adnan Bilge, ${ }^{1}$ Dr. Mehmet İrik, ${ }^{1}$ Dr. Halil Yılmaz ${ }^{1}$}

${ }^{1}$ Celal Bayar Üniversitesi Tıp Fakültesi, Acil Tıp Anabilim Dalı, Manisa

${ }^{2}$ Celal Bayar Üniversitesi Tıp Fakültesi, Radyoloji Anabilim Dalı, Manisa

AMAÇ: Günümüzde, kafa içi basıncın (KiB) belirlenmesinde, optik sinir kıllıf çapı (OSKÇ) ölçümlerinden faydalanılabileceği belirtilmektedir. KiB artışı, intrakraniyal yaralanmaların doğal bir sonucudur. Bu çalışmada, çok kesitli bilgisayarlı beyin tomografisindeki, pozitif intrakraniyal bulgular ve OSKÇ genişlemesi arasındaki ilişki değerlendirildi.

GEREÇ VE YÖNTEM: Toplam I6I hastanın çok kesitli BT görüntüleri geriye dönük incelendi. Ölçümler, kesitlerde optik sinirin en geniş görüldüğü bölge beş kez büyütülerek yapıldı.

BULGULAR: Çok kesitli beyin tomografisi görüntülerinde, 54 hastada kafa içi hasar tespit edilirken, 107 hastada edilmedi. Pozitif tomografi bulguları ile OSKÇ artışı arasında anlamlı ilişki olduğu belirlendi, $5.60 \pm 0.75 \mathrm{~mm}$ ve $5.35 \pm 0.75 \mathrm{~mm}(p=0.038)$. ROC eğrisinin altında kalan alan, 0.600 (\%95 güven aralığında $0.508-0.692$; $p<0.039$ ). OSKÇ eşik değeri $\geq 5 \mathrm{~mm}$, duyarlılık \%80, özgüllük \%36 olarak belirlendi.

TARTIŞMA: Bu çalışma, çok kesitli tomografilerde incelenen kafa içi hasar ile OSKÇ artışı arasında anlamlı ancak zayıf bir ilişki olduğunu gösterdi. Beyinde ciddi yapısal değişikliklere ve kanamaya yol açacak travmalar, optik sinirin genişlemesi üzerinde ancak sınırlı bir etkiye sahiptir.

Anahtar sözcükler: Beyin hasarı; bilgisayarlı tomografi; kafa içi basınç; kafa içi hipertansiyon; optik sinir klıfı çapı.

Ulus Travma Acil Cerrahi Derg 2018;24(4):316-320 doi: 10.5505/tites.2017.27985 